\title{
Keeping it in the family: The self-rated health of lone mothers in different European welfare regimes
}

ARTICLE in SOCIOLOGY OF HEALTH \& ILLNESS · NOVEMBER 2014

Impact Factor: 1.88 · DOI: 10.1111/1467-9566.12162

CITATION

1
READS

50

5 AUTHORS, INCLUDING:

Sarah Van de Velde

University of Antwerp

20 PUBLICATIONS 232 CITATIONS

SEE PROFILE

Terje A Eikemo

Norwegian University of Science and Techn..

53 PUBLICATIONS 794 CITATIONS

SEE PROFILE
Koen Van der Bracht

Ghent University

8 PUBLICATIONS 11 CITATIONS

SEE PROFILE

Piet F. Bracke

Ghent University

106 PUBLICATIONS 1,007 CITATIONS

SEE PROFILE 


\title{
Keeping it in the family: the self-rated health of lone mothers in different European welfare regimes
}

Van de Velde, S., Bambra, C., Van der Bracht, K. Eikemo, T. Bracke, P.

An adapted version of this paper has been published in Sociology of Health and Illness (2014)

\begin{abstract}
This study examines whether health inequalities exist between lone and cohabiting mothers across Europe, and how these may differ by welfare regime. Data from the European Social Survey are used to compare self-rated general health, limiting longstanding illness and depressive feelings by means of a multi-level logistic regression. The 27 countries included in the analyses are classified into six welfare regimes (Anglo-Saxon, Bismarckian, Southern, Nordic, Central-Eastern new-EU and Central-Eastern non-EU). Lone motherhood is defined as mothers not cohabiting with a partner, regardless of the legal marital status. Results indicate that lone mothers are more at risk of poor health than cohabiting mothers. This is most pronounced in the Anglo-Saxon regime for self-rated general health and limiting longstanding illness, while for depressive feelings it is most pronounced in the Bismarckian welfare regime. While the risk difference is smallest in the Central-Eastern regime, both lone and cohabiting mothers also reported the highest levels of poor health compared to the other regimes. Results also show that a vulnerable socioeconomic position is associated with ill-health in lone mothers, and that welfare regimes differ in the degree that they moderate this association.
\end{abstract}




\section{INTRODUCTION}

Previous research indicated that lone mothers, compared to cohabiting mothers are at higher risk of poverty, unemployment because of lack of affordable childcare, are employed in low-pay, lowstatus occupations, and are at higher risk of social exclusion (Lewis, 2006). Their disadvantaged socioeconomic situation is associated with a number of health problems. Compared to both married and unmarried cohabiting mothers, lone mothers are more likely to report general health problems (Burstrom et al., 2010, Fritzell et al., 2007, Whitehead et al., 2000), and mental health problems (Brown and Moran, 1997, Targosz et al., 2003). Lone mothers are therefore one of the most vulnerable groups in society. Variations between countries in the pattern of lone mothers' employment and poverty rates have been widely documented (e.g. Kilkey and Bradshaw, 1999). This suggests that welfare regimes may differ in the nature and quality of social rights conferred to women, and how paid work and care is reconciled. To date, analysis of the moderating effect of different welfare regime arrangements on the health status of lone mothers has been hampered by a lack of comparative crossnational data. The few studies that have looked at the topic present mixed results. Burstrom and colleagues (2010) found that the gap in health between lone and cohabiting mothers was smaller in Italy, than Sweden and Britain. Lahelma and colleagues (2002) found that in Britain, the disadvantaged social position of lone mothers accounted for a greater proportion of poor health than in Finland. In contrast, Whitehead and colleagues (2000) showed that the magnitude of the differential between lone and cohabiting mothers was similar in Sweden as compared to Britain. In this study, we are the first to make use of cross-national data from the European Social Survey which covers the general population in almost all European countries and covers the full geographical range of Europe. The data allow us to analyse to what extent inequalities in health exist between lone and cohabiting mothers and how this varies by welfare regime.

\section{THEORETICAL BACKGROUND}


Pathways leading to ill health are often explained using the stress-and-vulnerability model, which describes the relationship between the stressors the individual is exposed to and the way the individual reacts (Pearlin, 1989). Next to a number of biological and psychological risk factors, a large variety of social risk factors were identified in the literature. At the individual level, certain social positions are associated with different probabilities of exposures that are detrimental to health. For example, low education or unemployment is often associated with health risks such as bad housing, poverty, negative health behaviours, and overall feelings of powerlessness (Mirowsky and Ross, 2003). Whether an exposure leads to ill health or not is in part dependent on the presence of other risk factors as well. Lone mothers are often exposed to several health risks at once, and these may further interact to produce higher susceptibility (Fritzell et al., 2007).

The current literature on the health of lone mothers suggests a number of pathways to ill health. Most research focuses on their disadvantaged socioeconomic position; lone mothers are at higher risk of being without work; they are less likely to work full-time than other women, and they are more likely to be employed in low wage parts of the economy (Benzeval, 1998, Kilkey and Bradshaw, 1999). They are also less likely to have enjoyed education opportunities, putting them at a higher risk of poverty (eg. In Germany, $31 \%$ of lone mothers live in poverty compared to $8 \%$ of the total population. In Sweden, $11 \%$ versus $7 \%$; in the UK $40 \%$ versus 14\%; in Spain $29 \%$ versus $14 \%$ (LIS, 2000)).

The links between a disadvantaged socioeconomic position and ill health are well established (Mackenbach et al., 2008). In addition, as the sole carer of a child and the sole possible breadwinner in a family, the dual responsibility of lone mothers to provide both cash and care is likely to represent an extreme in the tensions between paid work and care responsibilities. Dual roles have been posited as a reason behind the inequalities in morbidity found amongst both men and women (author citation, 2008). Further, the literature on work-life balance, work-family conflict and work-care responsibilities suggests that imbalance and tensions in such relationships can be health damaging. For example, Netemeyer and colleagues (1996) found an association between increased work-family conflict and physical ill health, and Frone and colleagues (1997) found a strong association between work-family conflict and depression, poor physical health, hypertension and alcohol misuse. 


\section{Welfare Regimes and Lone Mothers}

Since Esping-Andersen's (1990) The Three Worlds of Welfare Capitalism, many researchers have used the concept of welfare regimes in comparative social policy research. His typology was based upon three dimensions: the nexus of state and market in the distribution system, the quality of social rights as reflected in decommodification, and the stratifying effects of welfare entitlements. While Esping-Andersen made a major contribution to the field of comparative macro social-policy research, criticisms were made of his original typology which mostly related to the limited number of countries included, their categorization within a certain regime, and the insufficient consideration of gender (Sainsbury 1999). Several alternative typologies have since been developed including those which integrate issues of defamilization alongside decommodification (e.g. author, 2007, Lewis, 1992). Defamilization refers to the extent to which a welfare regime undermines women's dependency on the family and facilitates women's economic independence (Lister, 1997). The structure of modern welfare regimes have never provided well for those who were marginal in some way to the labour market, as is the case with many lone mothers. In general, only widows have been able to rely on derived benefits, consisting of social insurance benefits paid for by their husbands' contributions. These are invariably higher than the mean-tested social assistance benefits that the growing proportion of divorced and unmarried mothers extract from the 'absent' father (Lewis, 2006). This is particularly important when considering how welfare regimes treat lone mothers.

Resonating with the recent recognition of the importance of the macro social and political context in determining health, many researchers have started to examine how different national welfare arrangements influence population health. The underlying assumption is that welfare regimes are important determinants not only of the socio-economic position, but also of health, as they mediate the health effects of socio-economic position. Welfare regimes can additionally help to explain gender differences in health as well, as they act as a force in ordering gender relations (author, 2008). They are deeply implicated in shaping women's access to an independent income. They may support women's waged labour, by providing services and cash transfers that reduce both the burden of women's domestic labour and the costs entailed in undertaking paid work (Orloff, 1996, Sainsbury, 
1999). Additionally, the welfare regime itself may present an important source of employment for women (Meyer, 1994). The type of welfare regime may also award those not engaged in the labour market with an independent income. Depending on the amount, method and conditions of payment, child benefits, extended parental leave-programs, social assistance when child-rearing responsibilities preclude the obligation to seek work, and carer's allowances can represent an important economic resource to women. Conversely, by not facilitating women's access to an independent income, welfare policies may also reinforce their dependency on men. Lone mothers' living conditions are therefore particularly sensitive to the setup of welfare policies and how women in such situations are treated, therefore may be the quintessential example of how welfare regimes construct the relationship between paid work and caring for all women (Kilkey and Bradshaw, 1999).

In the current study, we make use of Ferrera's (1996) typology, which distinguishes four welfare regimes: the Anglo-Saxon regime, the Nordic regime, the Bismarckian regime, and the Southern regime. They differ with respect to the main source of financing for care (private purchase, income taxation, pay-roll taxation), the main place where care takes place (private services, public services, the family), and the amount and the channels of resources directed to the needy (cash transfers or transfers in kind by the state, and private intra-family transfers). While the Anglo-Saxon and Nordic regimes are very different in design and final outcomes, they are similar because they foster more 'symmetric' gender relations. In contrast the Bismarckian and Southern welfare regimes are 'asymmetric', because they direct men and women towards different types of work, unpaid care work in the case of women and paid non-care work in the case of men (Addis, 2002). We prefer this typology to Esping-Andersen's classification, because in contrast to the latter, it is not only based on cash benefits, but also considers welfare services, including child care and social services which are of importance in terms of defamilization and gender stratification within a welfare regime (author, 2007). The Ferrera typology has also been used extensively in previous comparative sociology of health research (e.g. author, 2009, author, 2008) and has been shown to be empirically robust (author, 2007).

The first regime type groups the Nordic countries. It is characterized by a universalistic approach to social rights, a high level of decommodification, in addition to promoting gender equality both on the labour market and in care tasks (Fritzell et al., 2007). This benefits lone mothers in a 
number of ways. Subsidized public day care for children is widely available, encouraging high rates of employment among lone mothers (Allen, 2003). The provision of housing allowances supports families and lone mothers with limited incomes with good accommodations (Scheiwe, 2003). In addition, child maintenance transfers and other need-based social assistances schemes for lone mothers are provided by the state (Bergmark and Palme, 2003).

In contrast, the Anglo-Saxon welfare model provides only limited social insurance. Its social programs are directed mainly toward the working class and the poor, and means-tested assistance is prevalent. It grants mothers the time to care for their children by offering financial assistance on the basis of their caring status - although recent changes have placed age restrictions on this (for example in the UK there is now a requirement to seek work once the youngest child is 5 (Gibson et al., 2012). However, the regime is weak in respect of the social rights attached to paid work and the transition from care-giving to paid work, which may act to constrain lone mothers' choice to do other than fulltime caring (Gibson et al., 2012, Kilkey, 2000). There is only limited publicly funded child care. Therefore, lone mothers are predominantly full-time carers as opposed to being engaged in paid work, resulting in relatively high rates of poverty (Brady and Burroway, 2012).

The Bismarckian welfare regime was traditionally set up to support the male-breadwinner system, with a focus on cash-transfers to households rather than on the direct provision of services (Lewis, 2009). The family was traditionally selected as the unit of benefits, with welfare provisions being conferred upon the head of the household (Bussemaker and van Kersbergen, 1999). Female labour force participation is generally discouraged through tax disincentives or even explicit policies (van Kersbergen, 1995). A wife has been entitled to benefits only when she has become the head of the household through the death of her husband (widow pensions). Benefits for women in case of divorce have typically been absent. In recent years, some of the Bismarckian countries have adopted policies to facilitate child care with employment (Morel, 2007, Fleckenstein, 2011). The Netherlands provide high replacement rates for non- or part-time working lone mothers, while France and Belgium offer extensive service and parental employment rights. However, most other Bismarckian countries welfare policies show low levels of defamilization, encouraging women to at least partly take up the family and housekeeping responsibilities. 
The Southern welfare regime is typified by high levels of familialism as the family has a central role in the organization of both employment and welfare (Tavora, 2012). The state does not support the normal functioning of families, but only covers social risks against which the family cannot protect itself, such as the risk of death or the risk of losing a steady job for a worker (Trifiletti 2012). In contrast to the other welfare regimes, the extended, rather than the nuclear family often interacts with welfare agencies (Trifiletti, 1999). Generous protection is provided to full-time workers on the official labour market, while no guarantee of a minimum income is provided for those outside the labour market. Care work is taken for granted and female employment is low (Lewis et al., 2008a). However, women in employment almost always work full-time and, only in this case, get benefits and access to social services through their worker status. Because social protection covers women mainly on the basis of their marital status, special provisions for lone mothers are nearly absent (Lewis et al., 1994). In addition, unmarried and widowed mothers are often granted more provisions than divorced or separated lone mothers. However, the likelihood of full-time employment is considerably higher in lone mothers than cohabiting mothers (Fadiga Zanatta 1996), due to the lack of social protection, and the informal support from the extended family in care tasks.

In the current study we additionally incorporate a number of Central and Eastern European countries. The former socialist era supported women as workers and socialized many costs of motherhood and care work (Pascall and Lewis, 2004), resulting in relatively high female labour participation (Molyneux, 1990). However, this region has recently experienced extensive economic upheaval and has undertaken comprehensive social reforms throughout the 1990s (Kovacs, 2002). They have emphasized the liberal regime approaches of marketization, decentralization and the reform of health insurance schemes (Orenstein, 2008), putting people outside of the job market especially at risk of health problems. Along with mass unemployment, many of the social assistance provisions previously distributed through the workplace as well as public child care arrangements diminished. Women have been viewed as the "losers of the transformation process" (Klenner and Leiber, 2010) since employment among women decreased markedly and women were particularly affected by growing social inequality and poverty. In addition, most countries in this region have no special provisions for lone mothers, making them especially susceptible for health risks. 
Unfortunately, the comparative literature that tried to establish whether a type of CentralEastern welfare regime has emerged is mostly inconclusive. One path that might help identify different gender policies and welfare provisions is the literature that focuses on the convergence of new member states with the European Social Model (Vaughan-Whitehead, 2003, Draxler and Van Vliet, 2010, Sedelmeier, 2009). On the one hand, it has been suggested that the liberal reform agenda promoted by the EU (labour market deregulation and flexibilisation) exacerbated the already high inequalities in the new EU member states (Adascalitei, 2012), which may have had a negative effect on the national social policy systems. From this perspective, we would expect a poorer performance of new EU member states as compared to non (or recently accepted) member states. On the other hand, research found that new member states comply with EU gender equality legislation, and even outperform all the old member states. This might explain the higher ranking of these new member states on the Gender Inequality Index (UNDP, 2010), compared to the non- or recently accepted member states. Given the expected differences between new member states and the non-member states, we opt for this division in the upcoming analysis.

\section{Study aim and hypotheses}

The aim of the current study is threefold. First, we will determine whether lone mothers suffer more from health problems than cohabiting mothers in all welfare regimes. Different aspects of health are assessed by distinguishing between subjective general health, limiting longstanding illness and feelings of depression. In line with the available research, we expect that lone mothers will report more health problems than cohabiting mothers in all welfare regimes. Second, we will examine whether this health gap differs by type of welfare regime. We expect that welfare regimes with high levels of universalism and policies targeted at defamilization will benefit the health status of mothers in general. Welfare regime generosity is one of the most influential factors explaining cross-national differences in health risks such as poverty (Brady and Burroway, 2012). However, we expect that lone mothers will be even more sensitive to the setup of these welfare policies. Third, we will look at differences in the pathways linking lone motherhood to ill health, by examining well-established health risks such as poverty, low education and non-employment (Mackenbach et al., 2008, author, 
2010a). We expect that lone mothers in a vulnerable socioeconomic position are more prone to health problems than lone mothers who are not in a vulnerable socioeconomic position, but that the association between socioeconomic position and health is mediated by the type of welfare regime. Our study utilizes survey data from the European Social Survey, covering most European countries, which we categorize into five regimes based on Ferrera's (1996) classification, plus two additional categories for Central-Eastern Europe; the new-EU member states and the non-EU countries. Member states that were accepted in 2007 were not added to the cluster of new member states because the vast majority of data were collected before this date.

\section{METHODS}

\section{Data}

We based our analyses on data from the European Social Survey (ESS), which collected information on subjective health by means of three indicators: self-reported subjective general health, limiting longstanding illness and depressive feelings. The first two indicators were included in the first four ESS waves (2002-2008, covering 27 countries), while the depression-related indicator was only included in the third ESS wave (2006, covering 23 countries). The data and extensive documentation are freely available for downloading at the Norwegian Social Science Data Services website (www.nsd.uib.no), and an overview of which countries are clustered in specific welfare regimes, along with the sample sizes and response rates is provided in the online appendix (Table 1A). ESS information is representative for all individuals in the general population aged 15 and older living in a private household. Data were gathered via face-to-face interviews. In our analyses, we restricted ourselves to women, aged 18-55 years, with children aged 18 years or younger in the household. A weight was applied in all analyses to correct for design effects due to sampling designs in countries where not all individuals in the population have an identical selection probability. The merged data were additionally weighted to adjust for country presence across the different waves (= total number of respondents/total number of countries)/(number of respondents in country X). The unweighted 
sample consisted of 26,499 respondents (3619 lone mothers) in the merged dataset, and of 6603 (753 lone mothers) in the ESS wave 3 file.

Self-reported poor/fair general subjective health (GSH) was constructed from a variable asking; 'How is your (physical and mental) health in general?' Eligible responses were 'very good', 'good', 'fair', 'bad', and 'very bad'. We dichotomized the variable into 'very good or good health' versus 'less than good' health ('fair', 'bad', and 'very bad'). As for limiting longstanding illness (LLI), people were asked if they were hampered in daily activities in any way by any longstanding illness or disability, infirmity or mental health problem. Eligible responses were 'yes a lot', 'yes to some extent' and 'no'. We dichotomized this variable into 'yes' (regardless of whether to some extent or a lot) and 'no'. Depressive feelings (DF) were assessed using an eight-item version of the Center for Epidemiologic Studies Depression Scale (CES-D 8). Respondents were asked to indicate how often in the week previous to the survey they felt or behaved in a certain way (felt depressed, felt that everything was an effort, slept badly, felt lonely, felt sad, could not get going, enjoyed life, or felt happy). The latter two items were reverse coded. Response categories forming a 4-point Likert scale ranged from none or almost none of the time (0) to all or almost or all of the time (3). Scale scores for the CES-D 8 were assessed using unweighted summed rating and ranged from 0 to 24 , with higher scores indicating a higher frequency and severity of depressive complaints.

Lone motherhood was measured by comparing those who were living together with a partner, with those who were not cohabiting with a partner. Married person who were not living with their partner were included in the first group, while unmarried cohabiting mothers were included in second group. Therefore we captured the factual rather than legal status of cohabiting. We additionally controlled for whether another adult, besides the partner living in the household, such as a brother, parent(-in-law) or other (non-)relative (score 1) or not (score 0). Socioeconomic position was measured by employment status, educational level and presence of poverty. Employment status was coded as a dummy variable, with persons either in paid employment (1) or not (0). Educational level was measured by the total number of years in full-time education. Respondents who deviated more than three standard deviations from the national mean were capped off to the closest valid number. 
Poverty was defined as less than 50 percent of the country's median income (Not in poverty $=0$; in poverty $=1)$.

\section{Analysis}

We present two different tables and three figures to examine our three hypotheses. Table 1 presents separate prevalence rates of ill health for cohabiting mothers, for lone mothers, and the difference in prevalence rate of the two groups. For DF, we display the mean scores for each group along with the difference between both averages. Results were age standardized by means of the European Standard Population, using five year age groups. Unadjusted rates are provided in Table A3 in the Appendix. Table 2 presents the log-odds for GSH and LLI and effect sizes for DF of being a lone mother compared to a cohabiting mother (= reference category) for each welfare regime separately. Because of the dichotomous nature of GSH and LLI, logistic regression analyses were performed. We present the log-odds, which can be defined as the natural logarithm of the ratio of the odds that an event occurs in one group, compared to the odds that it occurs in the reference group. While the size of the log-odds is not intuitively interpretable, the direction of the log-odds is. A positive log-odds of lone mothers for instance indicates that lone mothers are more likely to be in poor health than cohabiting mothers. A negative log-odds indicates that lone mothers are less likely to be in poor health than cohabiting mothers. Given the continuous nature of DF, multilevel linear regression analyses were performed. A positive effect size implies that cohabiting mothers are more likely to report DF than lone mothers, while a negative effect size implies the opposite direction. Both log-odds and effect sizes are controlled for age and other adults in the household. The results presented in Table 1 enable us to examine health differences between cohabiting and lone mothers in all welfare regimes, thus examining our first hypothesis.

To assess whether the gap between cohabiting and lone mothers differs between welfare regimes, our second hypothesis, we perform multilevel analyses examining the association between ill health and lone motherhood in the different welfare regimes. Table 2 presents the results of these multilevel analyses for the three health indicators. The models include the main effect of lone motherhood (reference: cohabiting mother), the effects of the welfare regimes (reference: Anglo- 
Saxon regime) and of the interaction between these two effects. Results are controlled for age and other adults in the household. The Anglo-Saxon regime was selected as reference category because both health disparities and socioeconomic disparities between lone and cohabiting mothers were most pronounced in this regime. The main effect of lone motherhood indicates whether this group is more likely to be in poor health than cohabiting mothers are in the reference welfare regime, that is the Anglo-Saxon welfare regime. The main effects of the different welfare regimes represent how likely poor health is in cohabiting mothers (but not lone mothers) in each welfare regime. The interaction terms are used as a means to examine whether the health gap between lone and cohabiting mothers in a certain welfare regime differs significantly from the health gap in the Anglo-Saxon regime. A negative interaction term in combination with a positive effect coefficient in the reference category implies that the health gap between lone and cohabiting mothers is smaller in that welfare regime compared to the Anglo-Saxon welfare regime.

In order to investigate our last hypothesis, we limit the analyses to lone mothers. We examine whether certain welfare regimes are worse or better at attenuating health risks associated with a vulnerable socioeconomic position than our reference category (= lone mothers in a strong socioeconomic position within the Anglo-Saxon regime). Figures 1-3 display the relation between poor health and poverty, lower education or non-employment by welfare regime, for lone mothers only. Each bar indicates the difference in likelihood of poor health of the group studied to that of the reference category (= lone mothers in a strong socioeconomic position in the Anglo-Saxon welfare regime). The graphs do not contain a bar for this reference group, as they are used as a base for comparisons. Base numbers for poverty and employment in each welfare regime are presented in table A2 in the appendix. The figures are derived from the full results of multilevel analyses of all three dependent variables which are presented in tables A4-A6 in the appendix. Analyses were performed using the MLwiN statistical software package (version 2.26).

\section{Results}

From Table 1, we learn that there is considerable variation among welfare regimes in both the absolute level of ill health and the gap between cohabiting and lone mothers. Differences in the 
prevalence rates of lone and cohabiting mothers range between $1.42 \%$ to $9.50 \%$ for GSH, between $0.60 \%$ to $5.89 \%$ for LLI, and between 0.9 to 2.7 for DF. The log-odds confirm that lone mothers suffer more from ill-health than cohabiting mothers in all welfare regimes, apart from a few exceptions. Interestingly, the log-odds of poor GSH are not higher among lone than cohabiting mothers in the Southern welfare regime, while lone mothers in CE non-EU countries have lower log-odds of reporting poor GSH and similar levels of LLI as cohabiting mothers. At the same time, high rates of ill-health can also be observed in cohabiting mothers in the CE non-EU countries: the majority of cohabiting mothers report an ill health, while almost a quarter report a long-standing illness.

\section{TABLE 1 ABOUT HERE}

Table 2 presents the degree to which differences in health between lone and cohabiting mothers are moderated by welfare regimes. The results show that the health difference between lone and cohabiting mothers varies across welfare regimes. This can be examined by comparing the interaction terms of lone mothers with the different welfare regimes. As table 2 shows, the log-odds of all interaction terms are negative. Given that there is a significant positive main term of being a lone mother, this implies that the health gap between lone and cohabiting mothers is smaller in each of the welfare regimes than the health gap in the Anglo-Saxon regime. The difference in poor health is most pronounced in the Anglo-Saxon and Bismarckian welfare regime. Overall, the Nordic welfare regime seems to attenuate the health risks associated with lone motherhood best: of all welfare regimes, the gap is the smallest for DF and intermediate for poor GSH and LLI. This is also reflected in the absolute levels: lone mothers report the lowest rates of poor GSH and DF in the Nordic regime. However, their level of LLI is the highest of all welfare regimes.

\section{TABLE 2 ABOUT HERE}

To examine our last hypothesis, we limit the analyses to lone mothers only. Figures 1-3 display whether the relation between a vulnerable socioeconomic position and poor health in lone 
mothers is moderated by welfare regimes. Again, cohabiting mothers in the Anglo-Saxon regime act as reference group, specifically those who do not live in poverty, who are higher educated, and who are in paid employment. The bars in Figure 1-3 represent the log-odds of poor health in that specific group of lone mothers compared to the reference group. First, we confirm that in all welfare regimes, poverty, low education and non-employment are associated with a higher likelihood of poor health in lone mothers. However, certain welfare regimes are less able to buffer these health risks. In the AngloSaxon and Bismarckian welfare regime, lone mothers' health is most susceptible to poverty as compared to the other regimes. The association between lower education and poor health is quite universal. Only Bismarckian and Nordic welfare regimes succeed in attenuating the effects of lower education for lone mothers' health: lower educated lone mothers do not have significantly higher rates of DF than higher educated lone mothers. Finally, health differences between employed and nonemployed lone mothers are significantly more pronounced in the CE non-EU and CE new member states than in the other European welfare regimes. However, a closer look at the data reveals that the other welfare regimes might in fact also offer social protection to lone mothers in a less vulnerable socioeconomic situation. The baseline health of lone mothers in CE non-EU and CE new-EU countries is in fact worse than in the other welfare regimes (see Tables A4-A6 in Appendix). This means that the health of lone mothers in a weak socioeconomic position is worse in CE non-EU countries and to a lesser degree in CE new-EU countries compared to their peers in the other European welfare regimes, as can be seen from the graphs in figures 1-3.

We can conclude that poor, lower educated and non-employed lone mothers all have a significantly worse health status than lone mothers in a less vulnerable socioeconomic position, and that there is considerable variation in welfare regimes. Even though none of the welfare regimes prevail as the best, there are some who clearly perform worse than others. Lone mothers in AngloSaxon and Bismarckian countries are most vulnerable to socio-economic risk factors. Lone mothers in CE non-EU countries and to a lesser degree in CE new-EU countries, on the other hand, are less vulnerable but have, all things considered, a worse health status than other welfare regimes, leaving lone mothers in those countries with the poorest health of all welfare regimes. 
FIGURES 1-3 ABOUT HERE

\section{DISCUSSION}

Our study provides evidence for the hypothesis that welfare regimes help to explain health differences between lone and cohabiting mothers. First, with a few exceptions, our data show that in all welfare regimes lone mothers suffer more from poor GSH, LLI, and DF than cohabiting mothers. This is in keeping with our first hypothesis and is in line with the majority of the existing research literature (Targosz et al., 2003, Benzeval, 1998, Crosier et al., 2007).

Second, we found that the size of the health gap between lone and cohabiting mothers varies across welfare regimes. Our findings are in line with the research findings of Lahelma and colleagues (2002), which established a larger health difference between lone and cohabiting mothers in Great Britain than Sweden, and contradicted those of Burstrom and colleagues (2010), who found the opposite, as well as Whitehead and colleagues (2000) who could not establish any difference between welfare regimes.

Third, our findings are consistent with a vast body of sociological research that documents how social disadvantage is associated with elevated exposure to stressful life events (Avison et al., 2007). We found that non-employment, poverty and lower education all associate with higher rates of poor health in lone mothers. While the effect of education was universal across all welfare regimes, some welfare regimes were better than others at moderating the health risks associated with nonemployment and poverty.

In our study, the health difference between lone and cohabiting mothers is most pronounced in the Anglo-Saxon regime and the Bismarckian regime. Especially the health of cohabiting mothers is better than in the other regimes. It could be that the levels of social protection offered by the AngloSaxon are more effective in buffering or preventing health risks among cohabiting mothers, but less so for lone mothers. This finding is surprising, given that Anglo-Saxon welfare policies specifically target the most vulnerable groups in society. For example, the UK has until very recently maintained a 
relatively generous policy towards lone parents, exempting them from work requirements until their youngest child reaches sixteen (Gibson et al., 2012). Regardless, lone mothers were still at much higher risk for poverty, with $66 \%$ of lone parent families occupying the lowest two income quintiles, as compared to $23 \%$ of couple families in the UK (Maplethorpe, 2010). This may also be reflected in our results, with poverty most strongly related to ill-health among lone mothers in the Anglo-Saxon regime. Despite the high levels of poverty among lone mothers in the UK, restrictions on availability of social security benefits to lone parents were introduced by the government between 2008 and 2012 . These benefit restrictions were introduced with the ostensible intention to tackle poverty by promoting employment among lone mothers (Gibson et al., 2012).

The Bismarckian welfare regime is similar in the sense that social policies are mainly based on male-breadwinner principles, by discouraging female labour force participation, particularly in low income-jobs. This is done by offering low-income women to make use of long and low-paid parental leave schemes. For higher income women, various measures facilitating the use of private forms of childcare were developed (Morel, 2007). While the various schemes are open to all working families, in practice the use of each of these schemes is very much determined by the family's and especially the women's income level. The available parental leave benefits have been too low to attract higherincome earners, but have proven very attractive to low-income women (Morel, 2007, Lewis et al., 2008b). These types of measures may however keep lone mothers off the labour market, because they are more susceptible to be employed in low-income jobs (Misra et al., 2007). It is interesting to note that both the Bismarckian and the Anglo-Saxon regime, which during the time of the data-collection applied non-encouraging employment policies to lone mothers, also report the largest differences in health between lone and cohabiting mothers.

In contrast, both the Nordic and Southern welfare regimes encourage lone mothers to be in employment, though this is achieved in very different ways. The Southern welfare regime provides generous social protection to people who are in full-time employment, but no protection is provided to those outside the labour market. This combined with the lack of universal childcare services, results in employment rates for women being far below the European average (Boeri et al., 2005). However, 
employment rates of lone mothers are among the highest (Del Boca and Vuri, 2007). A likely explanation is the provision of childcare by family members combined with the pressure on lone mothers to earn their own income. We found that the difference in health between lone mothers and cohabiting mothers is rather small, with the rates of GSH and DF at an intermediate level, but levels of LLI far below average in both cohabiting and lone mothers.

Overall, the Nordic welfare regime seems to be equally able at overcoming the health risks of lone motherhood than the Southern regime. Because of the Nordic regime's high levels of universalism and gender-symmetric policies, we expected that the health status of lone and cohabiting mothers would be best off in this regime. A recent study by Brady and Burroway (2012) found that means-tested targeted programs towards lone mothers were less effective in reducing health risks such as poverty, than welfare universalism. Scholars have argued that welfare universalism is more effective because of its social policies tend to be more extensive, and it has also been associated with less health risks for all groups. In that sense, the better health status of lone mothers in universalist welfare regimes such as the Nordic regime might also be a by-product of its broader social equality. This is indeed reflected in substantially lower than average rates of DF and intermediate levels of poor GSH among both cohabiting and lone mothers in the Nordic regime. However, LLI is higher is the Nordic regime compared to the other welfare regimes. Some research proposed that the effect of relative deprivation may be more extensive in the Nordic welfare regime (Author, 2009, Author, 2008), which might in our case explain why the Nordic model does not perform best across the whole line.

Finally, in the CE non-EU and CE new-EU welfare regimes, both cohabiting and lone mothers overall levels of ill health are high. This is most pronounced in the non-EU CE countries, with more than half of both cohabiting and lone mothers reporting poor GSH and one fourth reporting LLI, and having the highest rates of DF in both groups of women. Both Central-Eastern welfare regimes thus seem least able to moderate many of the health risk that affect both cohabiting and lone mothers. High prevalence rates of ill health in the $\mathrm{CE}$ region, and especially the non-EU regime as compared to the rest of Europe have also been confirmed in previous studies (GERO, 2010, Witvliet et al., 2013). Several suggestions have been put forward as explanations of this East-West divide, eg. various behavioural 
patterns, such as heavy smoking and drinking (Peto et al., 1992, Carlson, 1998, Laaksonen et al., 2001, Helasoja et al., 2006), insufficient health care provisions and the social stagnation and social disorganization of these societies after the fall of communism (Bobak et al., 2007, Stuckler et al., 2009, Watson, 1995). While family policy benefits in this region have been relatively generous, unemployment benefits have been underdeveloped, resulting in low effectiveness in terms of redistribution and alleviation of poverty (Ferrarini and Sjöberg, 2010). This might explain why the association between lone motherhood and non-employment as well as poverty is strongest in this region.

Our results additionally show that there is substantial variation in health within the Central-Eastern region, with the new-EU member states performing better than the non-EU member states in the level of GSH and LLI. However, the level of DF is similar in both regimes. Entering the European Union has triggered the ambition of the new-EU member states to introduce West European institutional arrangements. In this context, it was the Bismarckian model of social protection that seemed to have enjoyed most popularity (Ferrarini and Sjöberg, 2010). The current literature studying CEE welfare regimes unfortunately has not yet reached a consensus on what explains their variation, their different trajectories or the extent of their transformation. Current research is hampered by the limited number of studies on the topic and the inconsistency of the available findings. Depending on which variable is used, clustering of the countries differs. For example, studies using parental leave regulations (Ciccia and Verloo, 2012) to subdivide the region differ from those based on childcare services (Szelewa and Polakowski, 2008), as well as on flexibility of working time (Tang and Cousins, 2005). This lack of consensus presents a major challenge for future research on welfare regimes and gender equality in Europe.

Our study has some important implications for European societies. Given the significant prevalence of lone mothers in some countries, and their increased occurrence in most advanced 
capitalist countries, lone mothers are not simply a marginal case in the sphere of social rights (Hobson 1994). Data from the UK for example, show a sharp increase of single headed households. In 1971, just eight percent of households were headed by a lone parent, but by 2011 that figure had reached 22 percent (GLS, 2011). Research on the health of this group of women does not only give us a unique way of studying welfare regimes, but also tells us how a rising group of women are treated by society and underpins the importance of defamilising welfare regimes within the context of an increasingly feminized European workforce.

\section{Limitations}

Some limitations of our study are worth noting when interpreting the results. Although the ESS-3 presents an outstanding opportunity for comparisons of health differences in lone and cohabiting mothers across welfare regimes, some of the issues that affect the comparability of multicountry studies, like selective non-response, differential modes of data collection, translation and conduct, may not be eliminated completely. If these issues are related to any of the health indicators or the independent variables, some bias in the estimates cannot be excluded. Our study is further limited because it utilizes only self-reported measures, and these may vary by country, culture and position within society (vandeVijver, 2003). However, a multigroup confirmatory factor analysis based on the CES-D 8 scale in the third wave of the ESS has shown that feelings of depression can be compared validly between the nations and sexes (author., 2010b). An additional limitation relates to the low number of lone mothers used for some parts of the analysis. While poor GSH and LLI were examined using four waves of the European Social Survey, DF were only assessed in a single wave, making the sample size of lone mothers much smaller.

Second, the varying prevalence rates of the different health measures included in our analysis indicate that these measures capture distinctive aspects of health, rather than a general underlying subjective well-being index. Our data also revealed different patterns across welfare regimes in the association between poor health and a vulnerable socioeconomic position. Further research is needed to explain these specific patterns across and within welfare regimes. 
Finally, we defined lone motherhood on the basis of the factual situation of whether or not someone is cohabiting with a partner, regardless of her current marital status. We were therefore better able to capture health risks related to the dual responsibility of sole child care and income maintenance. However, welfare provisions exclusively granted to lone mothers based on their marital status are not captured in this operationalization. In addition, the extent to which couples share responsibilities and resources is variable, making the situation of some cohabiting mothers akin to that of lone mothers. Similarly, some non-resident fathers may maintain responsibilities in the functions of child-rearing, making the distinction between lone-mother families and cohabiting families blurred. Moreover, the emergence of alternative living arrangements among cohabiting families, 'living apart together', for example, may also weaken the distinction. Bearing these reservations in mind, the current study was interested in lone mothers as mothers who in the absence of a partner must assume sole or primary responsibility for the material and emotional well-being of their children. 
Table 1: prevalence rates, differences in rates and multilevel log-odds or effect sizes of cohabiting and lone mothers by welfare regime

\begin{tabular}{|c|c|c|c|c|c|c|c|c|c|c|c|c|c|}
\hline & \multicolumn{4}{|c|}{ Poor/fair general subjective health } & \multicolumn{4}{|c|}{ Limiting long-standing illness } & \multicolumn{5}{|c|}{ Depressive feelings } \\
\hline & $\begin{array}{l}\text { Cohabiting } \\
\text { mothers (\%) }\end{array}$ & $\begin{array}{c}\text { Lone } \\
\text { mothers } \\
(\%)\end{array}$ & Log-odds & S.E. & $\begin{array}{l}\text { Cohabiting } \\
\text { mothers (\%) }\end{array}$ & $\begin{array}{c}\text { Lone } \\
\text { mothers (\%) }\end{array}$ & Log-odds & S.E. & $\begin{array}{l}\text { Cohabiting } \\
\text { mothers } \\
\text { (Ave.) }\end{array}$ & $\begin{array}{l}\text { Lone } \\
\text { mothers } \\
\text { (Ave.) }\end{array}$ & Difference & Effect & S.E. \\
\hline Anglo-Saxon & $12.70 \%$ & $22.20 \%$ & $0.726 * * *$ & $(0.105)$ & $12.81 \%$ & $17.20 \%$ & $0.642 * * *$ & $(0.012)$ & 5.53 & 7.02 & 1.5 & $2.390 * * *$ & $(0.223)$ \\
\hline Bismarckian & $20.90 \%$ & $29.00 \%$ & $0.515^{* * *}$ & $(0.131)$ & $14.58 \%$ & $19.40 \%$ & $0.514 * * *$ & $(0.080)$ & 5.70 & 7.41 & 1.7 & $2.078 * * *$ & $(0.469)$ \\
\hline Nordic & $19.43 \%$ & $21.20 \%$ & $0.310 * * *$ & $(0.093)$ & $22.41 \%$ & $28.30 \%$ & $0.309 * * *$ & $(0.052)$ & 4.65 & 5.56 & 0.9 & $0.898^{*}$ & $(0.451)$ \\
\hline Southern & $22.60 \%$ & $24.90 \%$ & 0.049 & $(0.159)$ & $6.24 \%$ & $7.30 \%$ & $0.355 * *$ & $(0.133)$ & 5.64 & 7.40 & 1.8 & $1.354 * *$ & $(0.488)$ \\
\hline New-EU & $34.25 \%$ & $40.92 \%$ & $0.346^{* * *}$ & $(0.081)$ & $16.61 \%$ & $17.21 \%$ & $0.175^{* *}$ & $(0.065)$ & 6.35 & 9.03 & 2.7 & $2.256^{* * *}$ & $(0.564)$ \\
\hline Non-EU & $53.85 \%$ & $55.27 \%$ & $-0.181 *$ & $(0.080)$ & $24.29 \%$ & $26.40 \%$ & -0.115 & $(0.092)$ & 6.70 & 8.76 & 2.1 & $2.023^{* *}$ & (0.689) \\
\hline
\end{tabular}

$* \mathrm{p}<0.05 ; * * \mathrm{p}<0.01 ; * * * \mathrm{p}<0.001 ;$ two-sided tests; Cases are weighted at the individual and country level

Rates are age-standardized. Log-odds and effect sizes controlled for age and other adult in the household 
Table 2: Multilevel analyses results of poor/fair general subjective health, limiting longstanding illness and depressive feelings in lone and cohabiting mothers

\begin{tabular}{|c|c|c|c|c|c|c|}
\hline & \multicolumn{2}{|c|}{$\begin{array}{c}\text { Poor/fair general subjective } \\
\text { health }\end{array}$} & \multicolumn{2}{|c|}{ Limiting longstanding illness } & \multicolumn{2}{|c|}{ Depressive feelings } \\
\hline & Log-odds & (S.E.) & Log-odds & (S.E.) & Effect size & (S.E.) \\
\hline Intercept & $-3.806 * * *$ & $(0.393)$ & $-3.902 * * *$ & $(0.267)$ & $4.470 * * *$ & $(0.521)$ \\
\hline Age & $0.045^{* * *}$ & $(0.004)$ & $0.045^{* * *}$ & $(0.004)$ & $0.015^{*}$ & $(0.007)$ \\
\hline Adult in the $\mathrm{HH}$ & 0.129 & $(0.089)$ & $0.220 *$ & $(0.097)$ & -0.117 & $(0.186)$ \\
\hline Lone Mother & $0.726 * * *$ & $(0.105)$ & $0.642 * * *$ & $(0.012)$ & $2.390 * * *$ & $(0.223)$ \\
\hline Anglo-Saxon & Ref. & & Ref. & & Ref. & \\
\hline Bismarckian & 0.605 & $(0.373)$ & 0.231 & $(0.230)$ & 0.011 & $(0.417)$ \\
\hline Nordic & 0.403 & $(0.334)$ & $0.753 * * *$ & $(0.210)$ & -0.561 & $(0.425)$ \\
\hline Southern & 0.750 & $(0.485)$ & $-0.514^{*}$ & $(0.238)$ & 0.762 & $(0.562)$ \\
\hline Eastern EU & $1.311 * * *$ & $(0.360)$ & $0.435^{*}$ & $(0.218)$ & $1.307 *$ & $(0.621)$ \\
\hline Eastern Non-EU & $2.157 * * *$ & $(0.622)$ & 0.789 & $(0.475)$ & $1.688 * *$ & (0.557) \\
\hline Lone Mother * Anglo-Saxon & Ref. & & Ref. & & Ref. & \\
\hline Lone Mother * Bismarckian & -0.212 & $(0.168)$ & -0.128 & $(0.083)$ & -0.312 & $(0.516)$ \\
\hline Lone Mother * Nordic & $-0.416^{* *}$ & $(0.141)$ & $-0.334 * * *$ & $(0.053)$ & $-1.492 * *$ & $(0.504)$ \\
\hline Lone Mother * Southern & $-0.677 * * *$ & $(0.191)$ & $-0.288^{*}$ & $(0.132)$ & $-1.036^{*}$ & $(0.522)$ \\
\hline Lone Mother $*$ Eastern EU & $-0.380 * *$ & $(0.132)$ & $-0.467 * * *$ & $(0.066)$ & -0.134 & $(0.607)$ \\
\hline Lone Mother * Eastern non-EU & $-0.907 * * *$ & $(0.133)$ & $-0.757 * * *$ & $(0.097)$ & -0.367 & $(0.729)$ \\
\hline Country variance & 0.279 & $(0.075)$ & 0.085 & $(0.035)$ & 0.290 & $(0.109)$ \\
\hline$\underline{\text { Individual variance }}$ & 3.290 & & 3.290 & & 15.199 & $(0.791)$ \\
\hline
\end{tabular}

$* \mathrm{p}<0.05 ; * * \mathrm{p}<0.01 ; * * * \mathrm{p}<0.001 ;$ Two-sided tests; Cases weighted at the individual level.

$\mathrm{N}_{\mathrm{i}}=25,394 ; \mathrm{N}_{\mathrm{i}}=27 ;$ Depression: $\mathrm{N}_{\mathrm{i}}=6,039 ; \mathrm{N}_{\mathrm{i}}=23$. 
Figure 1: The association between a vulnerable socioeconomic position and poor/fair general subjective health for lone mothers only across welfare regimes: interaction terms between welfare regimes and (1) poverty, (2) lower education and (3) non-employment

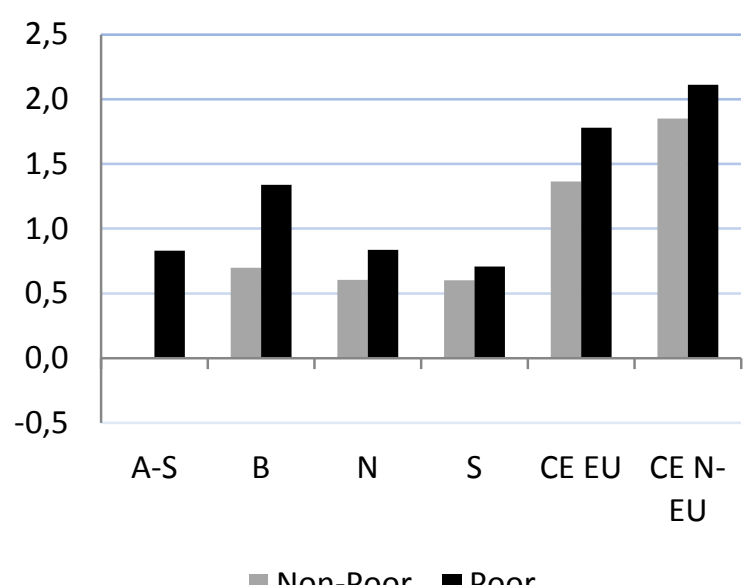

Non-Poor a Poor

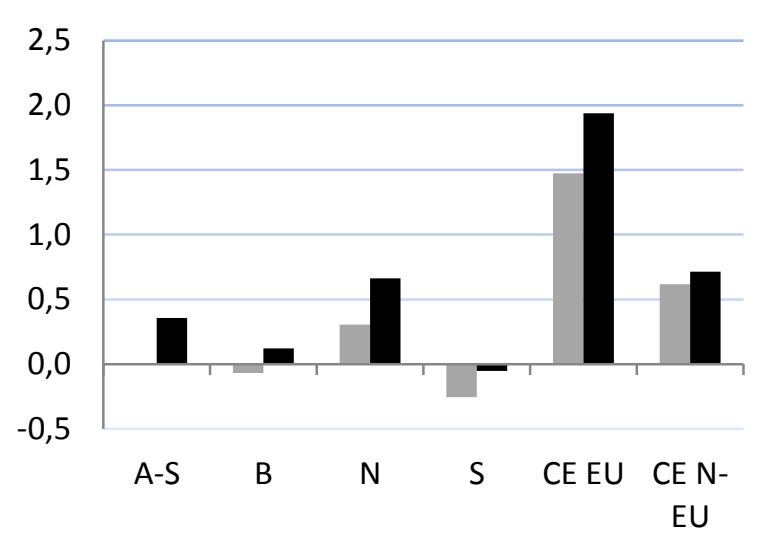

Higher educated $\quad$ Lower educated

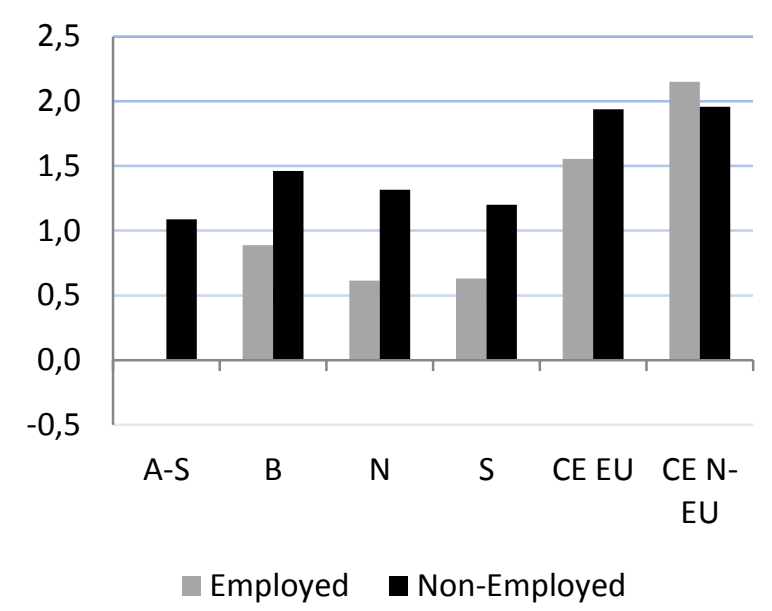

Employed Non-Employed

Figure 2: The association between a vulnerable socioeconomic position and limiting longstanding illness across welfare regimes: interaction terms between welfare regimes and (1) poverty, (2) lower education and (3) non-employment

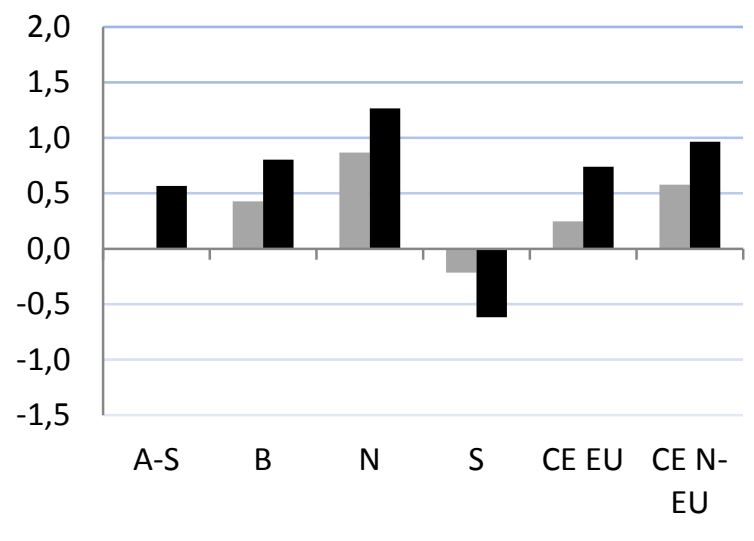

Non-Poor $\mathbf{n}$ Poor

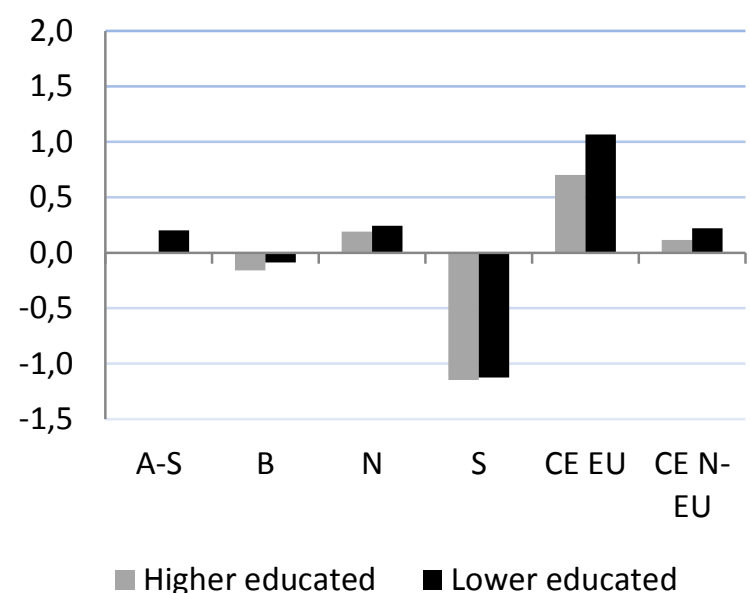

Higher educated $\quad$ Lower educated

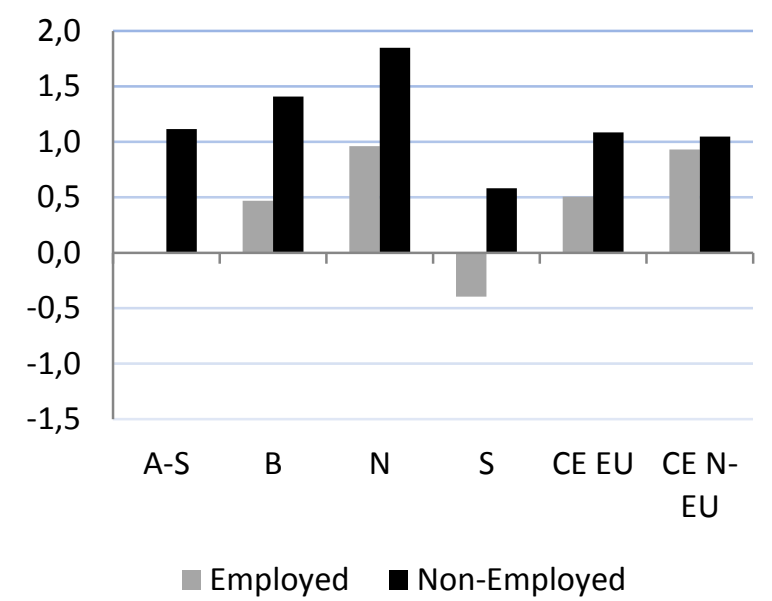

Employed Non-Employed 
Figure 3: The association between a vulnerable socioeconomic position and depressive feelings across welfare regimes: interaction terms between welfare regimes and (1) poverty, (2) lower education and (3) non-employment

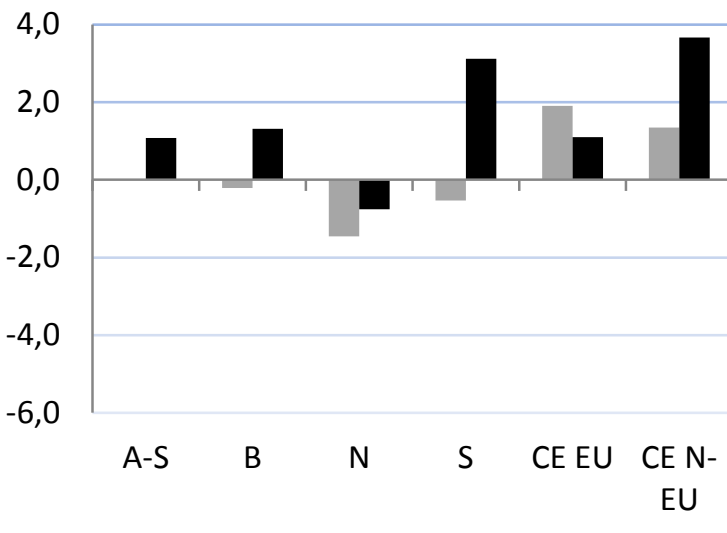

Non-Poor Door

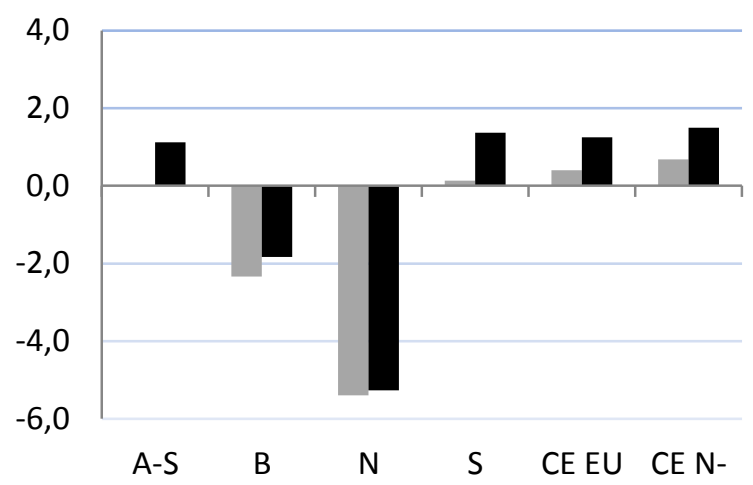

Higher educated

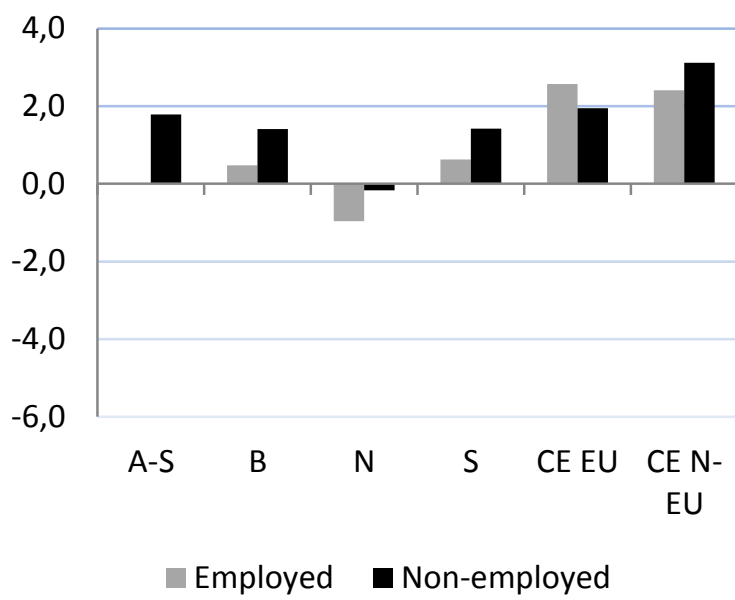


ADASCALITEI, D. 2012. Welfare State Development in Central and Eastern Europe: A State of the Art Literature Review. Studies of Transition States and Societies, 4.

ADDIS, E. 2002. Gender Symmetry In the Reform of European Welfare States. San Domenico di Fiesole, Italy.

ALLEN, S. 2003. Working parents with young children: cross-national comparisons of policies and programmes in three countries. International Journal of Social Welfare, $12,261-273$.

AVISON, W., ALI, J. and WALTERS, D. 2007. Family structure, stress, and psychological distress: A demonstration of the impact of differential exposure. Journal of Health and Social Behavior, 48, 301-317.

Author citation. 2007.

Author citation. 2009.

Author citation. 2008.

BENZEVAL, M. 1998. The self-reported health status of lone parents. Social Science and Medicine, 46, 1337-1353.

BERGMARK, A. and PALME, J. 2003. Welfare and the unemployment crisis: Sweden in the 1990s. International Journal of Social Welfare, 12, 108-122.

BOBAK, M., MURPHY, M., ROSE, R. and MARMOT, M. 2007. Societal characteristics and health in the former communist countries of Central and Eastern Europe and the former Soviet Union: a multilevel analysis. Journal of epidemiology and community health, 61, 990-996.

BOERI, T., DEL BOCA, D. and PISSARIDES, C. 2005. Women at work: an economic perspective, Oxford University Press.

BRADY, D. and BURROWAY, R. 2012. Targeting, universalism, and single-mother poverty: a multilevel analysis across 18 affluent democracies. Demography, 49, 719-746.

BROWN, G. and MORAN, P. 1997. Single mothers, poverty and depression. Psychological Medicine, 27, 21-33.

BURSTROM, B., WHITEHEAD, M., CLAYTON, S., FRITZELL, S., et al. 2010. Health inequalities between lone and couple mothers and policy under different welfare regimes - The example of Italy, Sweden and Britain. Social Science and Medicine, 70, 912-920.

BUSSEMAKER, J. and VAN KERSBERGEN, K. 1999. Contemporary Social-Capitalist Welfare States and Gender Inequality. In: SAINSBURY, D. (ed.) Gender and welfare state regimes. Oxford: Oxford University Press.

CARLSON, P. 1998. Self-perceived health in East and West Europe: another European health divide. Social science and medicine, 46, 1355-1366.

CICCIA, R. and VERLOO, M. 2012. Parental leave regulations and the persistence of the male breadwinner model: Using fuzzy-set ideal type analysis to assess gender equality in an enlarged Europe. Journal of European Social Policy, 22, 507-528.

CROSIER, T., BUTTERWORTH, P. and RODGERS, B. 2007. Mental health problems among single and partnered mothers. Social psychiatry and psychiatric epidemiology, 42, 6-13.

DEL BOCA, D. and VURI, D. 2007. The mismatch between employment and child care in Italy: the impact of rationing. Journal of Population Economics, 20, 805-832.

DRAXLER, J. and VAN VLIET, O. 2010. European social model: No convergence from the East. European Integration, 32, 115-135.

Author citation. 2008.

ESPING-ANDERSEN, G. 1990. The three worlds of welfare capitalism, Cambridge, Polity Press. 
FERRARINI, T. and SJÖBERG, O. 2010. Social policy and health: transition countries in a comparative perspective. International Journal of Social Welfare, 19, S60-S88.

FERRERA, M. 1996. The southern model of welfare in social Europe. Journal of European Social Policy, 1, 17-37.

FLECKENSTEIN, T. 2011. The Politics of Ideas in Welfare State Transformation: Christian Democracy and the Reform of Family Policy in Germany. Social Politics: International Studies in Gender, State and Society, 18, 543-571.

FRITZELL, S., WELTOFT, G., FRITZELL, J. and BURSTROM, B. 2007. From macro to micro: The health of Swedish lone mothers during changing economic and social circumstances. Social Science and Medicine, 65, 2474-2488.

FRONE, M., YARDLEY, J. and MARKEL, K. 1997. Developing and testing an integrative model of the work-family interface. Journal of Vocational Behavior, 50, 145-167.

GENERAL LIFESTYLE SURVEY. 2011. National Office for Statistics. http://www.ons.gov.uk/ons/rel/ghs/general-lifestyle-survey/2011/index.html

GERO, D. 2010. The east-west health divide in Europe: Growing and shifting eastwards.

GIBSON, M. and THOMSON, H. 2012. Welfare to work interventions and their effects on health and well-being of lone parents and their children (Protocol). The Cochrane Library.

HELASOJA, V., LAHELMA, E., PRÄTTÄLÄ, R., PATJA, K., et al. 2006. Determinants of daily smoking in Estonia, Latvia, Lithuania, and Finland in 1994-2002. Scandinavian journal of public health, 34, 353-362.

Author citation. 2009.

KILKEY, M. 2000. Lone mothers between paid work and care: the policy regime in twenty countries. University of York.

KILKEY, M. and BRADSHAW, J. 1999. Lone mothers, economic well-being, and policies. In: SAINSBURY, D. (ed.) Gender and welfare state regimes. Oxford: Oxford University Press.

KLENNER, C. and LEIBER, S. 2010. Welfare states and gender inequality in central and eastern Europe. Planning, 2013, 2014.

KOVACS, J. 2002. Approaching the EU and reaching the US? Rival narratives on transforming welfare regimes in East-Central Europe. West European Politics, 25, $175-+$.

LAHELMA, E., ARBER, S., KIVELA, K. and ROOS, E. 2002. Multiple roles and health among British and Finnish women: the influence of socioeconomic circumstances. Social Science and Medicine, 54, 727-740.

LEWIS, J. 1992. Gender and the development of welfare regimes. Journal of European social policy, 2, 159-173.

LEWIS, J. 2006. Children, changing families and welfare states, Cheltenham, Edward Elgar.

LEWIS, J. 2009. Work? Family Balance, Gender and Policy, Edward Elgar Publishing.

LEWIS, J., CAMPBELL, M. and HUERTA, C. 2008a. Patterns of paid and unpaid work in Western Europe: gender, commodification, preferences and the implications for policy. Journal of European Social Policy, 18, 21-37.

LEWIS, J., KNIJN, T., MARTIN, C. and OSTNER, I. 2008b. Patterns of development in work/family reconciliation policies for parents in France, Germany, the Netherlands, and the UK in the 2000s. Social Politics, 15, 261-286.

LEWIS, J., OSTNER, I., BREMEN, U. and FEUR SOZIALPOLITIK, Z. 1994. Gender and the evolution of European social policies, Centre for Social Policy Research, University of Bremen.

LIS 2000. Luxembourg Income Study.

LISTER, R. 1997. Citizenship: Feminist Perspectives. , London, MacMillan. 
MACKENBACH, J., STIRBU, I., ROSKAM, A., SCHAAP, M., et al. 2008. Socioeconomic inequalities in health in 22 European countries. New England Journal of Medicine, 358, 2468-2481.

MAPLETHORPE, N. 2010. Families with children in Britain: Findings from the 2008 Families and Children Study (FACS), Department for Work and Pensions.

MEYER, T. 1994. The German and British Welfare States as Employers: Patriarchal or Emancipatory? In: SAINSBURY, D. (ed.) Gendering Welfare States. Sage.

MIROWSKY, J. and ROSS, C. 2003. Social Causes of Psychological Distress, Hawthorne, New York, Aldine De Gruyter.

MISRA, J., MOLLER, S. and BUDIG, M. J. 2007. Work-Family Policies and Poverty for Partnered and Single Women in Europe and North America. Gender and Society, 21, 804-827.

MOLYNEUX, M. 1990. The Woman Question in the Age of Perestroika. New Left Review, 23-49.

MOREL, N. 2007. From Subsidiarity to 'Free Choice': Child-and Elder-care Policy Reforms in France, Belgium, Germany and the Netherlands. Social Policy and Administration, 41, 618-637.

NETEMEYER, R., BOLES, J. and MCMURRIAN, R. 1996. Development and validation of work-family conflict and family-work conflict scales. Journal of Applied Psychology, 81, 400-410.

ORENSTEIN, M. 2008. Out-liberalizing the EU: pension privatization in Central and Eastern Europe. Journal of European Public Policy, 15, 899-917.

ORLOFF, A. 1996. Gender in the welfare state. Annual Review of Sociology, 22, 51-78.

PASCALL, G. and LEWIS, J. 2004. Emerging gender regimes and policies for gender equality in a wider Europe. Journal of Social Policy, 33, 373-394.

PEARLIN, L. 1989. The Sociological-Study of Stress. Journal of Health and Social Behavior, 30, 241-256.

SAINSBURY, D. 1999. Gender and welfare state regimes, Oxford, Oxford University Press.

SCHEIWE, K. 2003. Caring and paying for children and gender inequalities: Institutional configurations in comparative perspective. Journal of Family History, 28, 182-198.

SEDELMEIER, U. 2009. Post-accession compliance with EU gender equality legislation in post-communist new member states. European Integration online Papers (EIoP).

STUCKLER, D., KING, L. and MCKEE, M. 2009. Mass privatisation and the postcommunist mortality crisis: a cross-national analysis. The Lancet, 373, 399-407.

SZELEWA, D. and POLAKOWSKI, M. P. 2008. Who cares? Changing patterns of childcare in Central and Eastern Europe. Journal of European Social Policy, 18, 115-131.

TANG, N. and COUSINS, C. 2005. Working Time, Gender and Family: An East-West European Comparison. Gender, Work and Organization, 12, 527-550.

TARGOSZ, S., BEBBINGTON, P., LEWIS, G., BRUGHA, T, et al. 2003. Lone mothers, social exclusion and depression. Psychological Medicine, 33, 715-722.

TAVORA, I. 2012. The southern European social model: familialism and the high rates of female employment in Portugal. Journal of European Social Policy, 22, 63-76.

TRIFILETTI, R. 1999. Southern European welfare regimes and the worsening position of women. Journal of European social policy, 9, 49-64.

UNDP 2010. Gender Inequality Index.

Author citation. 2010a.

Author citation. 2010b.

VAN KERSBERGEN, K. 1995. Social Capitalism. A study of Christian democracy and the welfare state., London/New York, Routledge. 
VANDEVIJVER, F. 2003. Bias and equivalence. In: HARKNESS, J., VAN DE VIJVER, F. and MOHLER, P. (eds.) Cross-Cultural Survey Methods. New Jersey: Wiley and Sons.

VAUGHAN-WHITEHEAD, D. 2003. EU enlargement versus social Europe: The uncertain future of the European social model, Edward Elgar Publishing.

WATSON, P. 1995. Explaining Rising Mortality Among Men in Eastern-Europe. Social Science and Medicine, 41, 923-934.

WHITEHEAD, M., BURSTROM, B. and DIDERICHSEN, F. 2000. Social policies and the pathways to inequalities in health: a comparative analysis of lone mothers in Britain and Sweden. Social Science and Medicine, 50, 255-270.

WITVLIET, M., ARAH, O., STRONKS, K. and KUNST, A. 2013. Examining self-rated health of young Central and Eastern Europeans in the context of other world regions. The European Journal of Public Health. 


\section{Appendix}

Table A1: Response rate, Number of Lone Mothers and Number of Cohabiting Mothers in European Social Survey wave 3 as well as wave 1-4 combined.

Table A2: descriptive statistics of poverty, education and employment among lone mothers

Table A3: Prevalence rates, difference in rates and log-odds or effect sizes of cohabiting and lone mothers by welfare regime. Results not age-adjusted

Table A4: Multilevel analyses of GSH, LLI and DF: Welfare regime differences in the association between poverty and ill-health

Table A5: Multilevel analyses of GSH, LLI and DF: Welfare regime differences in the association between lower education and ill-health

Table A6: Multilevel analyses of GSH, LLI and DF: Welfare regime differences in the association between non-employment and ill-health 
Table A1: Response rate, number of lone mothers and cohabiting mothers in European Social Survey wave 3 as well as wave 1-4 combined.

\begin{tabular}{|c|c|c|c|c|c|c|c|}
\hline & & \multicolumn{3}{|c|}{ Wave 3 (2006) } & \multicolumn{3}{|c|}{ Waves combined (2002-2008) } \\
\hline & & $\begin{array}{l}\text { Response } \\
\text { rate }(\%)\end{array}$ & $\begin{array}{l}\text { Cohabiting } \\
\text { Mothers }\end{array}$ & $\begin{array}{l}\text { Lone } \\
\text { Mother }\end{array}$ & $\begin{array}{l}\text { Average } \\
\text { response rate } \\
(\%)\end{array}$ & $\begin{array}{l}\text { Cohabiting } \\
\text { Mothers }\end{array}$ & $\begin{array}{l}\text { Lone } \\
\text { Mother }\end{array}$ \\
\hline \multirow[t]{2}{*}{ Anglo-Saxon } & UK & 52.1 & 301 & 85 & 54.2 & 809 & 245 \\
\hline & Ireland & 50.4 & 272 & 51 & 56.0 & 1019 & 195 \\
\hline \multirow[t]{4}{*}{ Nordic } & Denmark & 50.8 & 200 & 32 & 59.1 & 858 & 151 \\
\hline & Finland & 64.4 & 208 & 30 & 69.2 & 742 & 142 \\
\hline & Norway & 64.4 & 239 & 52 & 64.0 & 897 & 170 \\
\hline & Sweden & 65.5 & 257 & 50 & 65.8 & 799 & 144 \\
\hline \multirow[t]{7}{*}{ Bismarckian } & Austria & 64.0 & 379 & 58 & 62.3 & 1071 & 146 \\
\hline & Belgium & 61.0 & 255 & 35 & 60.1 & 762 & 133 \\
\hline & Switzerland & 50.0 & 268 & 24 & 45.2 & 892 & 109 \\
\hline & Germany & 52.9 & 295 & 67 & 50.6 & 719 & 154 \\
\hline & France & 46.0 & 320 & 46 & 45.7 & 987 & 155 \\
\hline & Luxembourg & - & - & - & 47.0 & 922 & 104 \\
\hline & Netherlands & 59.8 & 287 & 38 & 60.7 & 1039 & 130 \\
\hline \multirow[t]{5}{*}{ Southern } & Cyprus & 67.3 & 174 & 9 & 74.2 & 948 & 83 \\
\hline & Spain & 66.2 & 246 & 25 & 61.5 & 803 & 77 \\
\hline & Greece & - & & & 77.7 & 994 & 67 \\
\hline & Italy & - & & & 51.5 & 904 & 60 \\
\hline & Portugal & 72.7 & 265 & 47 & 72.1 & 767 & 119 \\
\hline \multirow[t]{6}{*}{ CE new-EU } & Czech Rep. & - & & & 56.0 & 716 & 118 \\
\hline & Estonia & 65.0 & 148 & 41 & 60.8 & 714 & 218 \\
\hline & Hungary & 66.0 & 196 & 50 & 65.7 & 795 & 164 \\
\hline & Poland & 70.0 & 219 & 30 & 72.0 & 899 & 96 \\
\hline & Slovenia & 64.9 & 163 & 16 & 66.0 & 720 & 87 \\
\hline & Slovakia & 73.2 & 220 & 22 & 72.9 & 726 & 91 \\
\hline \multirow[t]{3}{*}{ CE non-EU } & Bulgaria & 64.8 & 187 & 24 & 69.9 & 814 & 80 \\
\hline & Russia & 69.5 & 302 & 94 & 68.5 & 710 & 226 \\
\hline & Ukraine & 66.7 & 240 & 36 & 64.2 & 854 & 155 \\
\hline Total & & 62.1 & 5641 & 962 & 61.9 & 22882 & 3617 \\
\hline
\end{tabular}


Table A2: Descriptive statistics of poverty, education and employment among lone mothers

\begin{tabular}{|c|c|c|c|c|c|c|c|c|c|c|c|c|c|c|c|c|c|c|c|c|}
\hline & \multicolumn{10}{|c|}{ ESS Waves 1-4 (2002-2008) } & \multicolumn{10}{|c|}{ ESS Wave 3 (2006) } \\
\hline & \multicolumn{2}{|c|}{ Non-Poor } & \multicolumn{2}{|r|}{ Poor } & \multicolumn{2}{|c|}{ Employed } & \multicolumn{2}{|c|}{ Non-employed } & \multicolumn{2}{|c|}{ Education } & \multicolumn{2}{|c|}{ Non-Poor } & \multicolumn{2}{|r|}{ Poor } & \multicolumn{2}{|c|}{ Employed } & \multicolumn{2}{|c|}{ Non-employed } & \multicolumn{2}{|c|}{ Education } \\
\hline & \# & $\%$ & $\#$ & $\%$ & $\#$ & $\%$ & $\#$ & $\%$ & Ave. & \# & $\#$. & $\%$ & $\#$ & $\%$ & $\#$ & $\%$ & $\#$ & $\%$ & Ave. & S.D. \\
\hline Anglo-Saxon & 342 & $(42.5 \%)$ & 463 & $(57.5 \%)$ & 342 & $(42.5 \%)$ & 463 & $(57.5 \%)$ & 12.7 & 3.1 & 88 & $(44.2 \%)$ & 111 & $(55.8 \%)$ & 80 & $(40.2 \%)$ & 119 & $(59.8 \%)$ & 12.8 & 3.2 \\
\hline Bismarckian & 894 & $(69.5 \%)$ & 393 & $(30.5 \%)$ & 771 & $(59.9 \%)$ & 516 & $(40.1 \%)$ & 12.7 & 3.4 & 228 & $(71.0 \%)$ & 93 & $(29.0 \%)$ & 196 & $(61.1 \%)$ & 125 & $(38.9 \%)$ & 12.6 & 3.3 \\
\hline Nordic & 488 & $(71.4 \%)$ & 195 & $(28.6 \%)$ & 474 & $(69.4 \%)$ & 209 & $(30.6 \%)$ & 14.1 & 3.5 & 108 & $(66.3 \%)$ & 55 & $(33.7 \%)$ & 113 & $(69.3 \%)$ & 50 & $(30.7 \%)$ & 13.9 & 3.8 \\
\hline Southern & 342 & $(75.3 \%)$ & 112 & $(24.7 \%)$ & 345 & $(76.0 \%)$ & 109 & $(24.0 \%)$ & 10.9 & 4.4 & 73 & $(77.7 \%)$ & 21 & $(22.3 \%)$ & 70 & $(74.5 \%)$ & 24 & $(25.5 \%)$ & 10.6 & 4.5 \\
\hline CE EU & 526 & $(70.7 \%)$ & 218 & $(29.3 \%)$ & 473 & $(63.6 \%)$ & 271 & $(36.4 \%)$ & 12.5 & 3.1 & 98 & $(70.5 \%)$ & 41 & $(29.5 \%)$ & 86 & $(61.9 \%)$ & 53 & $(38.1 \%)$ & 12.5 & 3.3 \\
\hline CE Non-EU & 285 & $(66.1 \%)$ & 146 & $(33.9 \%)$ & 304 & $(70.5 \%)$ & 127 & $(29.5 \%)$ & 12.8 & 3.0 & 116 & $(65.9 \%)$ & 60 & $(34.1 \%)$ & 133 & $(75.6 \%)$ & 43 & $(24.4 \%)$ & 12.9 & 2.6 \\
\hline
\end{tabular}


Table A3: Prevalence rates of ill-health in cohabiting and lone mothers by welfare regime. Results not age-adjusted

\begin{tabular}{ccccccc}
\hline & \multicolumn{2}{c}{ GSH } & \multicolumn{2}{c}{ LLI } & \multicolumn{2}{c}{ DF } \\
& $\begin{array}{c}\text { Cohabiting } \\
\text { mothers (\%) }\end{array}$ & $\begin{array}{c}\text { Lone } \\
\text { mothers (\%) }\end{array}$ & $\begin{array}{c}\text { Cohabiting } \\
\text { mothers (\%) }\end{array}$ & $\begin{array}{c}\text { Lone } \\
\text { mothers (\%) }\end{array}$ & $\begin{array}{c}\text { Cohabiting } \\
\text { mothers } \\
\text { (Ave.) }\end{array}$ & $\begin{array}{c}\text { Lone } \\
\text { mothers } \\
\text { (Ave.) }\end{array}$ \\
\hline Anglo-Saxon & $12,5 \%$ & $22,8 \%$ & $11,1 \%$ & $19,1 \%$ & 5,06 & 7,49 \\
Bismarckian & $20,3 \%$ & $30,1 \%$ & $13,6 \%$ & $21,4 \%$ & 5,07 & 7,20 \\
Nordic & $16,4 \%$ & $21,7 \%$ & $20,2 \%$ & $26,4 \%$ & 4,50 & 5,39 \\
Southern & $23,4 \%$ & $27,2 \%$ & $7,0 \%$ & $10,1 \%$ & 5,87 & 7,42 \\
CE new-EU & $30,8 \%$ & $41,1 \%$ & $14,4 \%$ & $17,1 \%$ & 6,30 & 8,84 \\
CE Non-EU & $49,4 \%$ & $55,3 \%$ & $21,3 \%$ & $23,6 \%$ & 6,76 & 8,77 \\
\hline
\end{tabular}


Table A4: Multilevel analyses of GSH, LLI and DF: Welfare regime differences in the association between poverty and ill-health

\begin{tabular}{|c|c|c|c|c|c|c|}
\hline & \multicolumn{2}{|c|}{$\begin{array}{c}\text { Poor/fair } \\
\text { general subjective health }\end{array}$} & \multicolumn{2}{|c|}{ Limiting longstanding illness } & \multicolumn{2}{|c|}{ Depressive feelings } \\
\hline & Log-odds & (S.E.) & Log-odds & (S.E.) & Effect size & (S.E.) \\
\hline Intercept & $-2.938 * * *$ & $(0.328)$ & $-3.647 * * *$ & $(0.291)$ & $8.188 * * *$ & $(0.846)$ \\
\hline Age & $0.047 * * *$ & $(0.006)$ & $0.046^{* * *}$ & $(0.005)$ & 0.023 & $(0.017)$ \\
\hline Other adult in the $\mathrm{HH}$ & 0.230 & $(0.166)$ & 0.195 & $(0.174)$ & 0.247 & $(0.544)$ \\
\hline Poor & $0.832 * * *$ & $(0.073)$ & $0.568 * * *$ & $(0.062)$ & $1.077^{*}$ & $(0.519)$ \\
\hline Lower Education & $0.079 * * *$ & $(0.015)$ & $0.034^{*}$ & $(0.016)$ & $0.199 * * *$ & $(0.041)$ \\
\hline Non-Employed & $0.495 * * *$ & $(0.114)$ & $0.755^{* * *}$ & $(0.140)$ & $0.779 *$ & $(0.320)$ \\
\hline Anglo-Saxon & Ref. & & Ref. & & Ref. & \\
\hline Bismarckian & $0.700 "$ & $(0.418)$ & 0.427 & $(0.299)$ & -0.215 & $(0.370)$ \\
\hline Nordic & $0.604 "$ & $(0.349)$ & $0.868 * * *$ & $(0.258)$ & $-1.456^{* * *}$ & $(0.379)$ \\
\hline Southern & 0.603 & $(0.401)$ & -0.214 & $(0.314)$ & -0.539 & $(0.339)$ \\
\hline CE New-EU & $1.366^{* * *}$ & $(0.323)$ & 0.248 & $(0.238)$ & $1.903 * * *$ & $(0.554)$ \\
\hline CE Non-EU & $1.852 * * *$ & $(0.550)$ & 0.578 & $(0.400)$ & $1.347 * * *$ & $(0.225)$ \\
\hline Poor * Anglo-Saxon & Ref. & & Ref. & & Ref. & \\
\hline Poor * Bismarckian & -0.194 & $(0.174)$ & -0.192 & $(0.262)$ & 0.450 & $(0.873)$ \\
\hline Poor $*$ Nordic & $-0.599 *$ & $(0.257)$ & -0.172 & $(0.214)$ & -0.381 & $(1.150)$ \\
\hline Poor * Southern & $-0.726 * *$ & $(0.276)$ & $-0.970 *$ & $(0.414)$ & 2.575 & $(1.881)$ \\
\hline Poor * CE New-EU & $-0.417 * *$ & $(0.131)$ & -0.077 & $(0.164)$ & $-1.886^{*}$ & $(0.794)$ \\
\hline Poor $*$ CE Non-EU & $-0.571^{* *}$ & $(0.182)$ & -0.179 & $(0.440)$ & $1.240 "$ & $(0.723)$ \\
\hline Country variance & 0.252 & $(0.072)$ & 0.085 & $(0.035)$ & 0.420 & $(0.212)$ \\
\hline Individual variance & 3.290 & & 3.290 & & 15.199 & $(0.791)$ \\
\hline
\end{tabular}

" $\mathrm{p}<0.1 ; * \mathrm{p}<0.05 ; * * \mathrm{p}<0.01 ; * * * \mathrm{p}<0.001$; Two-sided tests; Cases weighted at the individual level.

$\mathrm{N}_{\mathrm{i}}=4,404 ; \mathrm{N}_{\mathrm{j}}=27$; Depression: $\mathrm{N}_{\mathrm{i}}=1,092 ; \mathrm{N}_{\mathrm{j}}=23$. 
Table A5: Multilevel analyses of GSH, LLI and DF: Welfare regime differences in the association between lower education and ill-health

\begin{tabular}{|c|c|c|c|c|c|c|}
\hline & \multicolumn{2}{|c|}{$\begin{array}{c}\text { Poor/fair } \\
\text { general subjective health }\end{array}$} & \multicolumn{2}{|c|}{ Limiting longstanding illness } & \multicolumn{2}{|c|}{ Depressive feelings } \\
\hline & Log-odds & (S.E.) & Log-odds & (S.E.) & Effect size & (S.E.) \\
\hline Intercept & $-2.398 * * *$ & $(0.263)$ & $-3.222 * * *$ & $(0.579)$ & $9.568 * * *$ & $(0.793)$ \\
\hline Age & $0.047 * * *$ & $(0.006)$ & $0.046^{* * * *}$ & $(0.005)$ & $0.027 "$ & $(0.016)$ \\
\hline Other adult in the $\mathrm{HH}$ & 0.221 & $(0.162)$ & 0.176 & $(0.173)$ & 0.268 & $(0.556)$ \\
\hline Poor & $0.428 * * *$ & $(0.082)$ & $0.366^{* *}$ & $(0.113)$ & $1.262 * *$ & $(0.422)$ \\
\hline Lower Education & $0.102 * * *$ & $(0.024)$ & 0.058 & $(0.058)$ & $0.320 * * *$ & $(0.020)$ \\
\hline Non-Employed & $0.496 * * *$ & $(0.112)$ & $0.759 * * *$ & $(0.137)$ & $0.738^{*}$ & $(0.316)$ \\
\hline Anglo-Saxon & Ref. & & Ref. & & Ref. & \\
\hline Bismarckian & -0.067 & $(0.332)$ & -0.158 & $(0.561)$ & -2.337 & $(1.490)$ \\
\hline Nordic & $0.305^{*}$ & $(0.146)$ & 0.193 & $(0.501)$ & $-5.395 * * *$ & $(0.903)$ \\
\hline Southern & -0.256 & $(0.611)$ & $-1.145^{*}$ & $(0.536)$ & 0.127 & $(0.776)$ \\
\hline CE New-EU & $1.475^{* * *}$ & $(0.330)$ & 0.704 & $(0.777)$ & 0.402 & $(1.312)$ \\
\hline CE Non-EU & 0.619 & $(1.178)$ & 0.116 & $(1.099)$ & 0.682 & $(1.068)$ \\
\hline Lower Education * Anglo-Saxon & Ref. & & Ref. & & Ref. & \\
\hline Lower Education * Bismarckian & -0.048 & $(0.038)$ & -0.038 & $(0.062)$ & $-0.176^{*}$ & $(0.079)$ \\
\hline Lower Education $*$ Nordic & 0.000 & $(0.025)$ & -0.043 & $(0.059)$ & $-0.283 * * *$ & $(0.046)$ \\
\hline Lower Education $*$ Southern & -0.043 & $(0.043)$ & -0.052 & $(0.062)$ & 0.035 & $(0.023)$ \\
\hline Lower Education * CE New-EU & 0.030 & (0.034) & 0.045 & $(0.075)$ & -0.076 & (0.098) \\
\hline Lower Education $*$ CE Non-EU & -0.075 & $(0.062)$ & -0.028 & $(0.083)$ & -0.086 & $(0.070)$ \\
\hline Country variance & 0.259 & $(0.073)$ & 0.085 & $(0.035)$ & 0.290 & $(0.109)$ \\
\hline Individual variance & 3.290 & & 3.290 & & 15.199 & $(0.791)$ \\
\hline
\end{tabular}

" $\mathrm{p}<0.1 ; * \mathrm{p}<0.05 ; * * \mathrm{p}<0.01 ; * * * \mathrm{p}<0.001$; Two-sided tests; Cases weighted at the individual level.

$\mathrm{N}_{\mathrm{i}}=4,404 ; \mathrm{N}_{\mathrm{j}}=27$; Depression: $\mathrm{N}_{\mathrm{i}}=1,092 ; \mathrm{N}_{\mathrm{j}}=23$. 
Table A6: Multilevel analyses of GSH, LLI and DF: Welfare regime differences in the association between non-employment and ill-health

\begin{tabular}{|c|c|c|c|c|c|c|}
\hline & \multicolumn{2}{|c|}{$\begin{array}{c}\text { Poor/fair } \\
\text { general subjective health }\end{array}$} & \multicolumn{2}{|c|}{ Limiting longstanding illness } & \multicolumn{2}{|c|}{ Depressive feelings } \\
\hline & Log-odds & (S.E.) & Log-odds & (S.E.) & Effect size & (S.E.) \\
\hline Intercept & $-3.097 * * *$ & $(0.305)$ & $-3.805 * * *$ & $(0.266)$ & $7.409 * * *$ & $(0.861)$ \\
\hline Age & $0.047 * * *$ & $(0.006)$ & $0.047 * * *$ & $(0.005)$ & 0.025 & $(0.016)$ \\
\hline Other adult in the $\mathrm{HH}$ & 0.261 & $(0.164)$ & 0.210 & $(0.170)$ & 0.360 & $(0.602)$ \\
\hline Poor & $0.426 * * *$ & $(0.081)$ & $0.372 * * *$ & $(0.113)$ & $1.212 * *$ & $(0.408)$ \\
\hline Lower Education & $0.078 * * *$ & $(0.015)$ & $0.034 *$ & $(0.015)$ & $0.197 * * *$ & $(0.039)$ \\
\hline Non-Employed & $1.087 * * *$ & $(0.083)$ & $1.117 * * *$ & $(0.104)$ & $1.785 * * *$ & $(0.337)$ \\
\hline Anglo-Saxon & Ref. & & Ref. & & Ref. & \\
\hline Bismarckian & 0.376 & $(0.383)$ & $0.469 "$ & $(0.272)$ & 0.471 & $(0.612)$ \\
\hline Nordic & 0.230 & $(0.329)$ & $0.963 * * *$ & $(0.274)$ & $-0.964 * *$ & $(0.343)$ \\
\hline Southern & 0.113 & $(0.397)$ & -0.396 & $(0.382)$ & 0.624 & $(0.530)$ \\
\hline CE New-EU & $0.850 *$ & $(0.367)$ & $0.508^{\prime \prime}$ & $(0.291)$ & $2.565 * * *$ & $(0.420)$ \\
\hline CE Non-EU & 0.869 & $(0.650)$ & $0.931 * *$ & $(0.359)$ & $2.407 * * *$ & $(0.433)$ \\
\hline Non-Employed * Anglo-Saxon & Ref. & & Ref. & & Ref. & \\
\hline Non-Employed * Bismarckian & $0.512 "$ & $(0.271)$ & -0.179 & $(0.235)$ & -0.846 & $(0.596)$ \\
\hline Non-Employed $*$ Nordic & 0.384 & $(0.271)$ & -0.233 & $(0.262)$ & -0.991 & $(0.723)$ \\
\hline Non-Employed $*$ Southern & 0.517 & $(0.324)$ & -0.140 & $(0.366)$ & -0.987 & $(0.874)$ \\
\hline Non-Employed * CE New-EU & $0.704 * * *$ & $(0.158)$ & $-0.541 "$ & $(0.325)$ & $-2.407 "$ & $(1.297)$ \\
\hline Non-Employed $*$ CE Non-EU & $1.282 * * *$ & $(0.179)$ & $-1.002 * * *$ & $(0.144)$ & $-1.077 "$ & $(0.638)$ \\
\hline Country variance & 0.257 & $(0.072)$ & 0.085 & $(0.035)$ & 0.434 & $(0.206)$ \\
\hline Individual variance & 3.290 & & 3.290 & & 15.126 & $(1.045)$ \\
\hline
\end{tabular}

" $\mathrm{p}<0.1 ; * \mathrm{p}<0.05 ; * * \mathrm{p}<0.01 ; * * * \mathrm{p}<0.001$; Two-sided tests; Cases weighted at the individual level.

$\mathrm{N}_{\mathrm{i}}=4,404 ; \mathrm{N}_{\mathrm{j}}=27$; Depression: $\mathrm{N}_{\mathrm{i}}=1,092 ; \mathrm{N}_{\mathrm{j}}=23$. 